\title{
Epidemiology of Pediatric Brain Tumor in the Center of Referral Hospital in North Sumatera from 2013 - 2017
}

\author{
Prawira Buntara Putra ${ }^{1}$, Ihsan Tala ${ }^{2}$, Ridha Dharmajaya ${ }^{3}$, Abdurrahman \\ Mouza $^{2}$, Steven Tandean ${ }^{2}$ \\ ${ }^{I}$ Resident, Department of Neurosurgery, Faculty of Medicine, Sumatera Utara University/RSUP. H. \\ Adam Malik Medan \\ ${ }^{2}$ Pediatric and Vascular Division, Department of Neurosurgery, Faculty of Medicine, Sumatera Utara \\ University/RSUP. H. Adam Malik Medan \\ ${ }^{3}$ Head of Departement, Department of Neurosurgery, Faculty of Medicine, Sumatera Utara \\ University/RSUP. H. Adam Malik Medan
}

\begin{abstract}
Brain tumors are the most common disease group of solid tumors in childhood, and children with brain tumors have a relatively poor survival rate. Epidemiologic data from a hospital-based registry provide the necessary information to obtain a full picture of the frequency of this disease, which is a great challenge in pediatric oncology. One hundred thirty four tumors in children between 0 and 17 years of age diagnosed between 2013 to 2017 were classified according the sex, and topography. Incidence of brain tumor in boys were higher than girls. From the registry data, the prevalence for boys was higher (67\%). In the whole series, $54 \%$ were supratentorial, $46 \%$ infratentorial. The most common histopathologic pattern seen in the registry were pilocytic astrocytoma which accounts for 42 cases (31\%) followed by medulloblastoma and craniopharygioma with the percentage of $25 \%$ and $18 \%$ respectively. The least histopathologic pattern of pediatric tumor seen in our center are diffuse astrocytoma and choroid plexus papiloma which was only seen in 1 patient for the last 5 years of our experience.
\end{abstract}

Keyword: Brain, Epidemiology, Histopatology, Pediatric, Tumor

\begin{abstract}
Abstrak. Tumor otak adalah kelompok penyakit yang paling umum dari tumor padat di masa kanak-kanak, dan anak-anak dengan tumor otak memiliki tingkat kelangsungan hidup yang relatif buruk. Data epidemiologis dari registri berbasis rumah sakit memberikan informasi yang diperlukan untuk mendapatkan gambaran lengkap tentang frekuensi penyakit ini, yang merupakan tantangan besar dalam onkologi pediatrik. Seratus tiga puluh empat tumor pada anak-anak berusia antara 0 dan 17 tahun yang didiagnosis antara 2013 hingga 2017 digolongkan menurut jenis kelamin, dan topografi. Insiden tumor otak pada anak laki-laki lebih tinggi daripada anak perempuan. Dari data registrasi, prevalensi untuk anak laki-laki lebih tinggi (67\%). Dalam keseluruhan seri, $54 \%$ adalah supratentorial, $46 \%$ infratentorial. Pola histopatologis yang paling umum terlihat dalam registri adalah astrositoma pilosit yang menyumbang 42 kasus (31\%) diikuti oleh medulloblastoma dan craniopharygioma dengan persentase masing-masing 25\% dan $18 \%$. Pola histopatologis terkecil dari tumor pediatrik yang terlihat di pusat kami adalah astrositoma difus dan choroid plexus papiloma yang hanya terlihat pada 1 pasien selama 5 tahun terakhir dari pengalaman kami.
\end{abstract}

Kata Kunci: Otak, Epidemiologi, Histopatologi, Pediatrik, Tumor

*Corresponding author at: prawira.putra@gmail.com

E-mail address: prawira.putra@gmail.com 
Received [15 Jan 2019] | Revised [1 Feb 2019] | Accepted [20 Feb 2019]

\section{Introduction}

Brain tumors are the most common disease group of solid tumors in childhood, and children with brain tumors have a relatively poor survival rate. Epidemiologic data from a hospital-based registry provide the necessary information to obtain a full picture of the frequency of this disease, which is a great challenge in pediatric oncology.[1][7] CNS tumors have emerged as the greatest challenge in pediatric oncology. In most countries of the world, brain and spinal cord tumors are second in frequency only to leukemia as a cancer affecting children, and are the most common cause of cancer mortality in the young. Moreover, compared with most other malignancies that occur during childhood, for CNS tumors there has not been a comparable success in treatment outcome. In this review, the incidence, mortality, and survival of children and adolescents up to 20 years of age will be reviewed, including trends that predict what the epidemiology and outcome will be for these patients in the year 2000.[2][8]

\section{Results}

Incidence of brain tumor in boys were higher than girls. From the registry data, the prevalence for boys was higher (67\%). In the whole series, 54\% were supratentorial, $46 \%$ infratentorial. The most common histopathologic pattern seen in the registry were pilocytic astrocytoma which accounts for 42 cases $(31 \%)$ followed by medulloblastoma and craniopharygioma with the percentage of $25 \%$ and $18 \%$ respectively. The least histopathologic pattern of pediatric tumor seen in our center are diffuse astrocytoma and choroid plexus papiloma which was only seen in 1 patient for the last 5 years of our experience

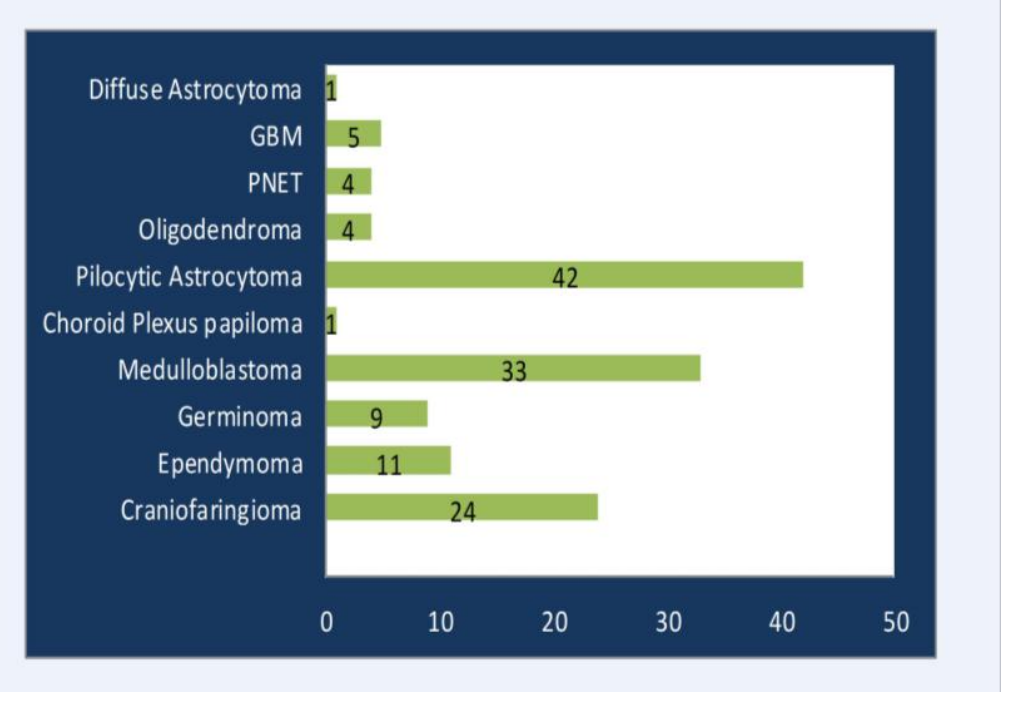

Figure.1 Epidemiology diagram of pediatric brain tumor by histopathologic result. 


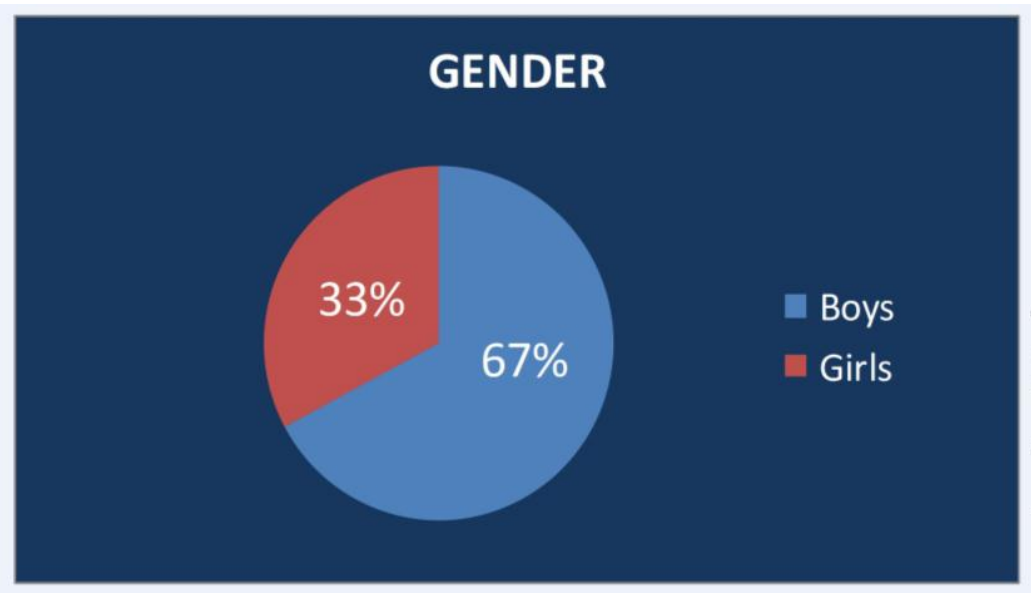

Figure 2. Percentage of pediatric brain tumor patient by gender

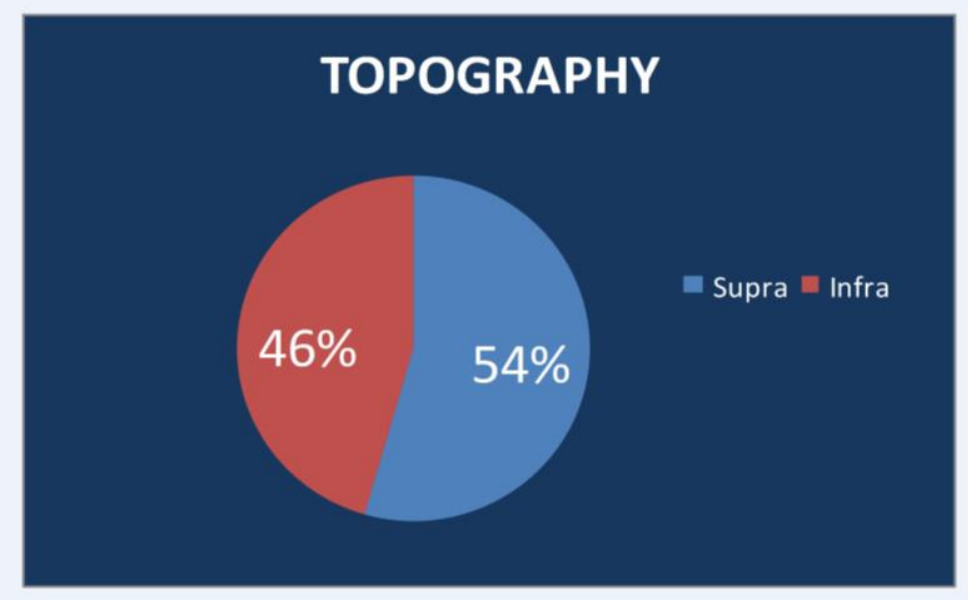

Figure 3. Topography of pediatric brain tumor patient between supratentorial and infratentorial

\section{Discussion}

According to projections of trends predicted from data collected by the United States Statistics, Epidemiology and End-Results (SEER) Program of the National Cancer Institute, the current incidence of cancer in American <20-year-olds is 16 cases per 100,000/year. Thus, approximately 11,000 United States children and adolescents under 20 years of age are diagnosed each year as having cancer, and 2,200 as having invasive CNS tumors. [3][4] On an average weekday, 42 children or adolescents are diagnosed with cancer, and 8-9 are found to have a CNS malignancy. Since 1945, about 280,000 children in the United States have been diagnosed with cancer before the age of 20 years, and about 50,000 of these children have been affected by a malignant CNS tumor. [5][6] In the United States, the overall incidence of malignant CNS tumors is inversely proportional to age, with 3.5-4 cases annually per 100,000 children $<5$ years of age, 3 per 100,000 5- to 10 -year-olds, 2.5 per 100,000 10- to 15-year-olds and 2.2 per 100,000 15- to 20-yearolds. Just over half (52\%) of the CNS malignancies in patients $<20$ years of age are astrocytomas, $21 \%$ are primitive neuroectodermal tumors (PNET), 
$21 \%$ are other gliomas, and $9 \%$ are ependymomas. Astrocytomas remain relatively independent of age, with a constant incidence of 1.5 per 100,000 per year over the first 20 years of life. PNETs, ependymoma and other gliomas each have a inverse relationship to age, which when combined accounts for most of the dependence of the overall CNS tumor incidence on age. [6]

In children less than 10 years of age, the most common site of malignancy within the CNS is the cerebellum. The second and third most common sites are the cerebrum and the brain stem, in which the frequency is relatively equal. Among 10- to 19-year-olds, the incidence of both cerebellar and brain tumors decreases, while cerebral maligancies increase in incidence. In adults, the most common location by far is the cerebrum. The incidence of malignant CNS tumors is higher in boys than in girls, with a ratio of 55\%:45\%. Most of this difference is accounted for by a male predominance in PNETs and ependymomas. There is little gender difference among the other basic tumor types. The higher rate in boys is far more prominent in white children than in Afro-Americans. White males $<20$ years of age clearly have a higher incidence rate of malignant CNS tumors (3.2/105 per year) than white females (2.5/105 per year), Afro-American females (2.3/105 per year), or AfroAmerican males (2.5/105 per year). [6]

\section{Conclusion}

Classified according to the latest WHO classification, by pathologist in a single institution, this series of pediatric neurological tumors registry may reflect fairly well their real incidence. Our results obtained in a developing country do not differ substantially from other similar series reported in the literature from the First World

\section{REFERENCES}

[1] Blayer.WA.Epidemiologic impact of children with brain tumors. Childs Nerv Syst:1999; 15:758-763

[2] Rickect C.H, Paulus W.Epidemiology of central nervous system tumors in childhood and adolescent based on the new WHO classification. Child Nerv Syst 2001; $17 ; 303511$.

[3] Ries LAG, Kosary CL, Hankey BF, Miller BA, Harras A, Edwards BK (eds) (1997) SEER cancer statistics review, 1973-1994. (NIH publication no 97-2789) NCI, Bethesda

[4] National Cancer Institute (1999) SEER pediatric monograph. NCI,

[5] Bleyer WA (1990) The impact of childhood cancer on the United States and the world. CA Cancer J Clin 40:355-367

[6] Gurney G, Smith MA, Bunin GR (1999) CNS and miscellaneous intracranial and intraspinal neoplasms. (National Cancer Institute SEER Pediatric monograph (to be published before the meeting), pp 51-63

[7] McLendon RE, Bigner DD, Bigner SH, et al (2000) Pathology of tumors of the central nervous system. Arnold, New York

[8] 8.Kaalsch P, Ricket CH, Kuhl J,Schus J, Mchaelis J, Population-based epidemiologic data on brain tumors in German Children.Cancer 2001; 15: 3155-3164 